\title{
Research on the Development of Online Financing and the Influences on Traditional Financial and Insurance Industry
}

\author{
Su Wei \\ Qinghai University of Finance and Economics College, Qinghai, Xining, 810001, China.
}

Keywords: Online Financing, Development, Traditional Financial, Insurance Industry.

\begin{abstract}
In this paper, we conduct research on development of online financing and the influences on traditional financial and the insurance industry. With the continuous development of the Internet economy, social networks, cloud computing, big data, and so on, more and more Internet applications to provide support for the traditional industry business development, the Internet's penetration in the traditional economy. Everyone in the exclamation of Internet financial mode of innovation and high efficiency at the same time, also in thinking about the Internet finance and traditional finance, the relationship between Internet financial for injected vitality, traditional financial is expected to open a new era of financial innovation. Under this basis, we propose the new perspective as implementation.
\end{abstract}

\section{Introduction}

Internet financial impact on the traditional financial system, in turn, lead to the emergence of the new forms of operation in the financial industry as may be in the future years of financial reality of China. Finance for all researchers, the Internet is a new research subject, is a chaotic and don't know the world. The basic connotation of Internet financial, operational structure, theoretical basis, business model, risk characteristics, alternative boundary, regulatory standards, etc., all need our system and the deep research. At present, there are two kinds of financial intermediary between capital supply and demand for financing amount, term and risk income matching one is commercial bank, another kind is corresponds to the indirect financing model stock and bond market, capital market corresponds to the mode of direct financing as these two kinds of the financing an important role in the allocation of resources and economic growth, but also need huge transaction costs [1-2].

Internet financial has a very wide range of business areas are involved, in the currency that fund securities, payment, online credit, all the areas of suggests basic innovative Internet financial business model to get explore. But look from the current status of the development of the Internet financial, third-party payment, funds financing and financing is the current online development relatively clear. Realizes the financial industry and Internet industry, the mutual integration of modern information technology industry as financial innovation business mode, establishing a new pattern of the financial business process and at present, our country financial model includes the following main all kinds of the Internet. (1) Crowd funding. So-called the raise, it is a kind of general group cooperation mode of financing, when some individual or the organization has new project launch, investors will be pooled funds through the network platform, to support the project and conduct. (2) Big financial data. Big financial data collection refers to the vast amounts of basic unstructured data, through carries on the real-time processing and correlation analysis, and its related parties for the financial institutions to provide professional, scientific and the decision support. (3) The Internet insurance. Comprehensive utilization of Internet insurance is represented by the Internet of a new generation of the information technology to realize the operation of basic insurance business. Compared to the traditional insurance operation mode, the Internet industry has low threshold, low cost of acquisition and transaction is easy and big data, etc. (4) Internet financial portal. Have already used the Internet to provide various types of financial information, with the rise of the Internet financial, the financial gateway to the Internet ushered in the great development opportunities. In short, the Internet financial portal is to point to by third-party financial services platform, to provide financial services of supply and demand both sides trading and information services that will formulate the novel form of the financial platform. 
To the Internet as a representative of modern information technology, especially mobile payments, social networks, search engines, and the cloud computing, etc., will be a disruptive impact on human financial model. May appear different from both the indirect financing of commercial bank, it is also different from direct financing capital market's third financial financing model. In the following list of sections, we will discuss the corresponding issues and challenges in detail.

\section{The Proposed Methodology}

Insurance Industry Characteristics. The particularity of the insurance industry is different from the other industry lies in the insurance contract and the insurance contract with the insurance risk transfer characteristics significantly. Insurance industry's accounting and measurement is actually recognition and measurement of insurance companies' insurance contract [3].

Insurance industry since its appearance has the significant social responsibility consciously that to guard against uncertain played an important role in specific risk, reduce the economic loss, insurance accounting is important step in the risk management of insurance industry, we should according to the particularity of the general insurance industry, insurance industry accounting for specific analysis and in-depth grasp, in order to impel the developing and perfecting of the insurance industry.

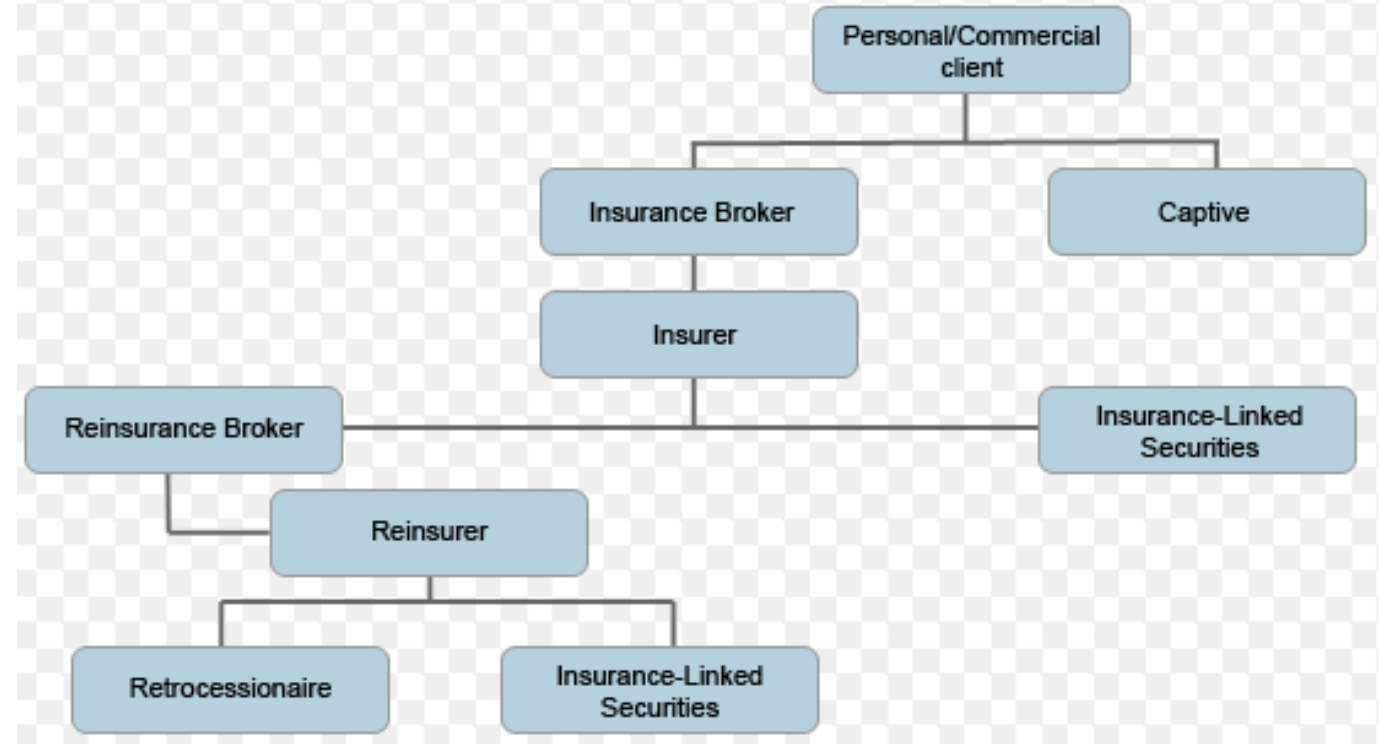

Fig. 1 The Systematic Architecture of the Insurance Industry

Honesty is the foundation of the insurance industry development as is the lifeblood of the industry. Insurance industry is a typical information asymmetry, adverse selection and moral hazard associated with insurance business activities. Credit insurance behavior is a kind of behavior, to the contract link and adjust interest relations and the parties of insurance product sales is good or bad depends on the insured's trust. Business development of the insurance industry is closely related to economic and the social environment, the cultural formation and development of the insurance industry will be the whole social cultural environment. A certain period of the social core values and widespread behavior will through various channels, the variety of the ways to the subtle influence of the whole insurance industry and their employees. Insurance as a kind of import, should absorb the advanced practice of the western developed country mature insurance market and concept, the good and discard the dregs, combined with the thoughts of Chinese traditional culture essence, form with Chinese insurance industry characteristics has the profound connotation and broad extension.

Traditional Financial System. Finance is the necessary way of comprehensively deepen reform, improve the financial market system. Traditional financial focus on high quality services to our clients and the long or hard to cover in the general financial field of the customer, namely, many small and medium-sized enterprises with development potential, micro enterprises, self-employed, farmers or the natural person customers. These small micro customers even only through the private lending loan sharks and other informal financial way to get the financial services they need, and these are in a 
state lack of regulation of informal financial services, not only expensive or harsh conditions, and easy to trigger social risk. Internet financial and fusion between traditional financial need and support, can we together to do the "cake". Rapid development of Internet financial, it is bound to in the journey of the traditional banking sector reform and transformation plays a dual role of challenger and catalyst.

Internet Financial Characteristics. Present, formal finance and informal finance field of force, respectively, from their respective advantages, at both ends, make Internet financial business mode is diversified development trend. But in basic essence, the current Internet finance mainly for financial instrumental application of information technology on the Internet, the Internet financial is "financial Internet" role in the Internet. In a word, the Internet plays are the role of financial information, the role of nature and not break through instrumental category, no matter how the instrumental performance in the application of multiple or change, the Internet financial behind the financial nature still distinct.

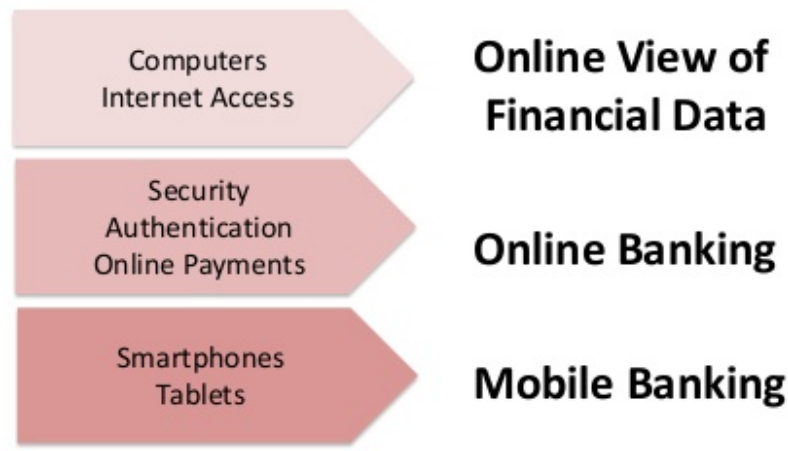

Fig. 2 The General Architecture of the Internet Financial System

Internet financial contained content is very broad, and that we are more interested in the Internet financial can bring innovation and breakthrough. Therefore, in addition to the central bank's focus on electronic currency, we will be divided into financial innovation at present domestic Internet payment innovation, channel innovation, investment and financing mode innovation and financial institutions.

Internet across time and space limit properties, and the increase of the social network geometry type information transmission efficiency drastically reduces the degree of information asymmetry, let the money supply and demand both the sides can achieve faster matching. So Banks and other traditional financial institutions allocate the attribute of financing in the weakened. P2P online credit, such as the suggests the financial mode of development, money supply and demand both sides no longer need the traditional financial intermediaries, but through the Internet platform and channel to realize matching, to further accelerate the pace of financial disintermediation [4-5].

$>$ Sources of innovation performance in traditional financial channels of virtualization. Internet effectively integrate transaction, payment and financing, such as business, breakthrough the limitation of the time and place, to provide the integrated and diversified financial solutions, promote the formation and development of virtual market.

$>$ Internet financial innovation is actually part of the investment and financing way instead of commercial bank credit intermediary function that greatly reduce lending both sides of the information asymmetry and transaction cost, to some extent is to address the issue of small and medium-sized enterprise financing and alternative folk financial effective attempt. Net lending money has many characteristics, such as the "short, sharp, small", is more focused on Banks ignore or do not take the area. Due to the admittance standard is too low, and lack of regulation as market demand response keen but face the future financial regulation tightening and the possibility of extrusion and incorporate into the banking system.

In this case, the financial institution innovation some general Internet companies through the application of the financial licenses of qualifications, acquisitions of small and medium-sized financial institutions, that joint licensed financial institutions into the financial sector, and to explore new financial institutions operating mode. Countries are to be encouraged about the folk capital into the financial sector with less control limits. 
Because of the Internet financial involved in the field are mainly concentrated in the field of traditional financial institutions to the current development is not deep, with the original traditional financial business complement, so in the short term the Internet finance from the angle of the size of the market will not make a big impact to the traditional financial institutions, but the Internet financial business model, innovative ideas, and its apparent efficiency for traditional financial institutions or bring the impact on the larger concept that also drove the fusion of traditional financial institutions to further accelerate with the Internet and the online based platforms.

Modern Financing Developmental Trend. In modern financial theory, a variety of financial economics model occupies a central position. Among them, still have a major impact on the results of mainly include: efficient market theory, portfolio theory, capital asset pricing model, arbitrage pricing theory, option pricing equation and asset structure theory.

With the development of the financing securitization, created a lot of different from the traditional commercial bank project on the balance sheet that namely the off-balance sheet business, some even more than the bank business several times in the table, it is an important content of banking business. Bank off-balance sheet business, also called no banking assets, intangible assets of the business, or below the bottom line of banking business and it refers to a bank or of industry revenue commitment or the activities of the contract, under traditional accounting procedures, not included in the assets and the liabilities, only make a comment on that the balance sheet, or in the offline, which reflected the essence of which is in an expansion of basic assets and liabilities at the same time, the commission or fee for business. Thus, liberalization, integration of the international financial market, with development of the off-balance sheet securitization, under the theme of peace and development is an important symbol of the human into a new civilization.

\section{Summary}

In this article, we conduct research on development of the online financing and the influences on traditional financial and insurance industry. We believe that current represented by mobile banking and financing Internet financial model provides a new investment and basic financing channels and convenience for the individual, to meet the financial needs of ordinary people, procedure is simple, flexible way is a beneficial supplement of the existing banking system, has rationality in economics, some problems in the development initial period is inevitable, not because a problem is to kill in a stick. Internet financial model certainly exist in many technical and business problems, to have the confidence to find a solution, not because today's difficult to ignore the future opportunities. In the future research, we will combine the reviews to propose the new perspectives for optimization.

\section{References}

[1] Škorić, Sanela, and Mato Bartoluci. "Financování chorvatských sportovních organizací v době hospodářské krize Financing Croatian sport organisations in time of economic crisis." STUDIA SPORTIVA (2015): 259.

[2] Templeman, Andre, et al. "Financing-Renewables: Renewable Energy Markets Challenged, but Strategies for Profit Still Exist." Natural Gas \& Electricity 29.11 (2013): 7-12.

[3] Hottenrott, Hanna, Bronwyn H. Hall, and Dirk Czarnitzki. "Patents as quality signals? The implications for financing constraints on R\&D." Economics of Innovation and New Technology (2015): 1-21.

[4] Harden, Jeffrey J., and Justin H. Kirkland. "Do Campaign Donors Influence Polarization? Evidence from Public Financing in the American States." Legislative Studies Quarterly 41.1 (2016): 119-152.

[5] Chen, Xia, Qiang Cheng, and Alvis K. Lo. "Accounting Restatements and External Financing Choices*." Contemporary Accounting Research 30.2 (2013): 750-779. 